\title{
THE GROWTH IN PENNSYLVANIA OF THE PROPERTY RIGHTS OF MARRIED WOMEN.*
}

In the extremely brief space permitted this paper on such a broad subject, it will only be possible to point out the marked contrast between existing legal conditions and what formerly constituted the law.

At the old common law of England, from which we in this State have drawn the substance of the principles of our law, when a woman entered the state of matrimony, the theory arose that her person in the eyes of the law became merged in that of her husband's. As a consequence her property was transferred by virtue of this legal fiction to him as follows: he became the absolute owner of whatever personal property was in possession of the wife, and such other personal property as bonds, notes and other choses in action; he could acquire complete property in them by reducing them to possession or, in other words, by taking such legal steps as were necessary to substitute himself in his wife's position as the holder of the legal or equitable title he acquired, under certain conditions, what is termed his curtesy in her real estate, the amount of this interest being a freehold estate not of inheritance in the wife's real property; and he became absolute master of the profits of her land during coverture.

At common law it was generally said marriage destroyed all powers of the woman to enter into a contract, and this was an effect also of the same theory of the destruction and obliteration of the legal existence of a married woman.

It would seem, however, that this theory, considered from the mere standpoint of a legal theory causing legal results to flow from its operation, is not entirely flawless, because it was possible for a married woman to have received a gift or a purchase provided she had her husband's assent to the transaction, and her choses in action remained in her legal

* This article was delivered as an address at the Commencement of the Temple College Law School in June, Igor, and as it was intended for a non-professional audience it was the author's effort to make it popular in form. 
possession until such time as the husband reduced them to his possession; again, it was possible for a married woman to enter into a contract, and this was not absolutely void, though generally said to be so, but only became void at her election, or the election of her husband when he chose to interfere.

In connection with the last proposition, it would seem the theory suggested, obiter dictum, by Mr. Justice Woodward, and also by other jurists and legal authorities, that a married woman is in law supposed to be sub potestate viri and therefore incapable of making a contract, is perhaps a more logical theory so far as her making and enforcing of contracts is concerned, though it is not generally approved.

Whether these criticisms are sound or not, the practical results were as stated, and in substance her property and contractual rights as a single woman were almost entirely destroyed, her legal existence for most purposes suspended. and other legal disabilities not to be properly considered here added to her estate when she became a married woman.

Such legal servitude was incompatible with the spirit of the founders of the Commonwealth and their descendants, and as was said in an opinion by Mr. Justice Agnew in I864: "Even before the passage of the Act of 1848 , custom and the common sense of justice had materially mitigated the rigor of that fiction, and equity had consistently refused to recognize the logical effect of a legal unity wherever by its rank injury it became legal folly."

Time cannot be taken in a paper of this general character to consider the smaller ameliorations effected by liberal judges, but only some of the larger and more important emancipations accomplished by legislative action can be briefly examined, without even indulging in the interesting study of the manner in which the various Acts were expounded and received their present construction by the Supreme Court.

The first legislative step for this purpose was the Act of I7I8, and it had in view the case of a wife left to shift for herself where her husband had gone to sea. It provided that such wife should have the right to trade as a feme sole, contract as such and sue or be sued without joining her husband. 
This Act had its provisions extended by the Act of 1855 to cases of desertion by or neglect of the husband to support his wife. But, under both Acts it was held that the wife, to become entitled to the benefit of the provisions, should be engaged in some trade, business or employment pursued as a means of livelihood; and if this were not so, she could not contract, sue or be sued under their provisions. The scope and purpose of these Acts are evidently to ameliorate the unfortunate condition of a woman under any of the above recited conditions, who otherwise might not be able to earn her living by any trade or business occupation. In this connection we might examine the Act of 1872 which provides that the earnings of any married woman "shall accrue to and inure to the separate benefit of said married woman" and not be subject to any legal claim of her husband. It was contended that this Act enabled any married woman to engage in trade or business, and by virtue of that circumstance she became a feme sole trader, but Mr. Justice Paxson in 1882 held that the Act of 1872 only secured to her her separate earnings and that there is no feme sole trading with us except those licensed under the Acts of $I 718$ and 1855 . And further, that the Act of 1872 by implication gave her the right to engage in business, and that to the extent of her rights and liabilities in relation to the business itself she is to be considered a feme sole. Before this Act of 1872 and notwithstanding the Act of 1848 , to which immediate reference will be made, the earnings of a married woman on their receipt by her became the property of her husband.

In I848 the legislature took a long step towards freeing married woman from their disabilities to hold their own property; in substance it was enacted that "every species of property which may be owned by a single woman shall continue to be her property as fully after marriage as before - . and all property which shall accrue during coverture shall be owned, used and enjoyed by such married woman as her ozen separate estate . . . and shall not be subject to levy and execution for her husband's debts. nor encumbered or conveyed by her husband without her written consent." One might, reading these provisions, be inclined to think that the very obvious purpose of the 
Act, after preserving her separate estate to her own use, was to enable a married woman to do almost anything she pleased with it. But this Act, as well as those which so far have been adverted to, is in derogation of the common law and therefore to be construed strictly. And when the words are carefully analyzed and considered, no general powers are found contained in them, but only certain special powers given, and such has been the effect given to the Act by the courts when appealed to. In a case where it was strongly urged that the Act gave general powers of contract to a married woman we find such language as this denying such proposition. First, alluding to the disabilities prior to the Act, the court said: "And the Act of 1848 did not and was not intended to change the law in this respect except to bind her separate estate in special cases and in the manner therein specified." The Act was therefore limited to its terms, and it was held that all the Act expressly did was to enable a married woman to own, use and enjoy her property as a married woman as if the property had been settled to her sole and separate use during coverture: and that such ownership involved no contractual powers of any kind except such as were indispensible to preserve such estate from ruin, and these rights rested upon the theory that the privelege to own, use and enjoy gave by implication the power to take care of it, and if this were not so the privilege would be an empty one; as was said in a per curiam opinion in I875: "If the roof of her house be blown off by storm or sink in utter decay so that the building becomes untenantable, what is to become of it if she cannot repair it." This narrow construction, however, was only reached after considerable doubt by the profession and it was thought by many that a more liberal one should have been given.

Prior to the Act of 1848 the property of a married woman could be taken in execution for the debts of her husband by his creditors. This Act put an end to that injustice, though it did not in any way interfere with the husband's right of curtesy in her estate. Against this interest in his wife's land his creditors still issued execution, but of course could not get possession until the wife's death. To remedy this 
evil the legislature in 1850 enacted that the husband's interest in his wife's land shall not be subject to execution and sale during the wife's life. This Act, however, made no mention of the lien of judgments against the husband attaching to his interest in the wife's property. To remedy this the legislature enacted in 1863 that the lien of no such judgment should attach to the real estate of the wife, nor upon the husband's interest as tenant by curtesy in her property during the lifetime of the wife.

The spirit of freedom which pervades our society had up to this point been aiming at the mere protection of married women, and had found expression in the legislative acts which have been cursorily examined. But the same spirit called for greater strides in the direction of freeing married women from the legal trammels that marriage imposed upon them. Mere protection had been accomplished, but had become insufficient to satisfy the growth of public sentiment which in innumerable ways was recognizing the legal, economic and personal equality of men and women in the married state. Accordingly, in 1887, an Act was passed which was intended not merely to protect the wife's property from the rapaciousness of her husband and his creditors, but aimed at giving to a married woman as large property and contractual rights as would be consistent with a proper protection, necessary for the inexperience in business affairs and easily influenced character of her sex.

The terms of this Act were by far the most sweeping of any of a similar kind that had been passed up to the time of its enactment, and indicated the clear purpose of the legislature that it should be construed in the same spirit as all prior ones of a similar kind had been, but that it was to be an enabling and an enlarging Act, and therefore it should receive such liberal and fair constructon as, in the words of Judge Endlich, in his book on the interpretation of statutes, "would advance the remedy aimed at by it so long as it does not go beyond its real object and scope." In r89I Paxson, C. J., speaking of the Act of I887 and of the powers given by it to a married woman, said: "So general is her power to contract now, that her inability is the exception rather than the rule." These words of the Chief 
Justice were adopted by Justice Green in I893, and fairly represent what was the attitude of our highest tribunal towards the Act. A few years of working experience under the Act showed that it was not as satisfactory as could be desired, and the profession saw that many points had been raised and could be still further raised, that were not fully covered by its terms. According, in 1893 an Act was passed intended to cover the discrepancies of the Act of 1887 , accomplish in a better way the same objects as the Act of 1887 , and which by its very terms repealed all laws inconsistent with it. The Act of I893 gave the same powers to a married woman to acquire, enjoy and dispose of any property as if she were an unmarried person, except she cannot convey or mortgage her real property without the joinder of her husband. She may make any contract, except she may not become accommodation indorser, maker, guarantor or surety for another. She may sue and be sued as an unmarried woman, but she may not sue her husband except under certain conditions and for certain objects. Thus at one blow almost all the remaining disabilities existing at common law in the case of a married woman were swept away. The purpose of this act is well stated by Mr. Justice Green in a case decided in 1895 . He said: "The Act of 1893 was intended to place the rights of a married woman upon a broader, more comprehensive and better defined basis than was accomplished by the Act of I887." And the effect of the Act is well stated by Justice Dean in 1895 . He said: "Formerly her capacity to contract was exceptional and her disability general; now her disability is exceptional and her capacity general."

These very words were incorporated in an opinion by President Judge Rice, of the Superior Court, in a case decided in I897. Together they are a good reflection of the mind of our courts of highest jurisdiction on the meaning of the Act of 1893 and the effect to be given to it.

The Acts of 1848,1887 and 1893 gave with certain restrictions to married women the power to dispose of their property by will and testament.

Of necessity it has only been possible in this paper to notice the most important of the forty odd Acts of legisla- 
ture passed with a view to emancipate married women from their legal disabilities.

The brief paper, which is the condensed result of considerable labor, is a good exemplification of the fact that the law is a progressive science, and shows that as economic and social conditions change, the law, as an integral part of the government, also changes, to keep step with the new and constantly arising necessities of the people and the State.

Charles O'Brien. 